\title{
The Arabian Camel, Camelus dromedarius \\ Interferon Alpha: Cloning, Expression in \\ Escherichia coli, in vitro Refolding and Cytotoxicity on Triple Negative Breast Cancer Cell Line MDA-MB-231
}

\author{
Hesham Saeed $^{1 *}$, Manal Abdel-Fattah ${ }^{1}$, Ahmad Eldoksh $^{1}$, Farid S. Ataya ${ }^{2}$ and \\ Manal Shalaby ${ }^{3}$ \\ ${ }^{1}$ Department of Biotechnology, Institute of Graduate Studies and Research, Alexandria \\ University, Alexandria, Egypt. \\ ${ }^{2}$ Biochemistry Department, College of Science, Riyadh, King Saud University, Saudi \\ Arabia. \\ ${ }^{3}$ Genetic Engineering and Biotechnology Research Institute (GEBRI), City for Scientific \\ Research and Technology Applications, New Borg Al-Arab City, Alexandria, Egypt.
}

\begin{abstract}
A B S T R A C T
The open reading frame encoding interferon alpha (IFN $\alpha$ ) of the camel liver, Camelus dromedarius was isolated and cloned using reverse transcription-PCR. Sequence analysis of that gene showed a 564bp encoding a protein of 187 amino acids with a predicted molecular weight of $21 \mathrm{kDa}$. Basic local alignment search tool (BLAST) sequence analysis revealed that $C$. dromedarius IFN $\alpha$ gene shares high sequence identity with IFN $\alpha$ genes of other species, including C. ferus, Vicugna pacos, and Homo sapiens. Expression of $C$. dromedarius IFN $\alpha$ cDNA in Escherichia coli revealed a fusion protein with a weight of $22.5 \mathrm{kDa}$ after induction of expression with IPTG for $5 \mathrm{~h}$. The recombinant IFN $\alpha$ was expressed in the form of inclusion bodies that were separated and solubilized in vitro and the protein was refolded using SDS and $\mathrm{KCl}$. The folded protein is then purified using on Ni-NTA Agarose affinity chromatography and the purity was judged by SDS-PAGE. Moreover, the effect of the recombinant IFN $\alpha$ of the viability of cancer cell line was assessed by MTT assay. Morphological study showed that $C$. dromedarius IFN $\alpha$ protein inhibited cell survival of MDA-MB-231 triple negative breast cancer cells.
\end{abstract}

Article Information
Received 20 April 2020
Revised 30 May 2020
Accepted 02 June 2020
Available online 04 June 2021
Authors' Contribution
HS supervised the experiments and
prepared the manuscript. MA con-
ducted the experiments evaluated the
results. AE evaluated and validated
the results. FA supervied the study and
did some experiments. MS helped in
manuscript revision and preparation.
Key words
Camelus dromedaries, Cloning,
Expression, Inclusion bodies,
Interferon

\section{INTRODUCTION}

$\mathrm{T}$ he term interferon (IFN) was first coined by Alick Isaacs and Jean Lindemann in 1957 at the National Institute for Medical Research in London to describe an antiviral compound produced by virus infected chick cells that were able to interfere with viral infection (Isaacs and Lindemann, 1957). Since then, research pertaining to the discovery, characterization, and development of novel IFNs has continued for over 60 years (Meager, 2009). IFNs belong to a pleiotropic family of cytokines that play an important role in controlling cellular growth and apoptosis, and in the response to infections (Kaplan et al., 2017). IFNs are glycosylated proteins having molecular weight ranging from 20 to $25 \mathrm{kDa}$. They are produced in response to a variety stimuli including viral, bacterial,

\footnotetext{
Corresponding author: hsaeed1@ksu.edu.sa 0030-9923/2021/0004-1525 \$ 9.00/0

Copyright 2021 Zoological Society of Pakistan
}

parasitic infections, inflammation, and tumorigenesis by various body cells like epithelia, endothelia, stroma, and cells of the immune system (Baldo, 2014; Borish and Steinke, 2003; Vacchelli et al., 2013; Peng et al., 2007). IFNs play important role in cell proliferation and differentiation, activation of immune cells, chemotaxis, inflammation, and apoptosis (Tayal and Kalra, 2008; Vacchelli et al., 2012). IFNs are classified-based on the receptors they interact with-into three major classes namely, type I, II, and III. Each type is encoded from different gene and has specific chromosomal localization, protein structures and biological activity (Fischer et al., 2018). Type II and III IFNs consist only of IFN $\gamma$ and IFN while type I IFN consists of IFN $\alpha, \beta, \delta, \varepsilon, \zeta, \kappa$, , and $\omega$ (Klotz et al., 2017). The most common cytokine that has the longest record of use in clinical oncology is Type I IFN $\alpha$ as it is used in over 40 countries for the treatment of hematological malignancies and certain solid tumors such as melanoma, renal carcinoma, and Kaposi's sarcoma (Meager, 2009; Ferrantini et al., 2007). Moreover, 
recombinant IFN- $\alpha 2 b$ is used for the treatment of recurrent melanomas (Cooksley, 2004) and IFN- $\alpha$ for the treatment of Hepatitis B and C, and HIV in combination with other antiviral drugs (Shepherd et al., 2000). Although different subtypes of IFN $\alpha$ essentially bind to the same receptors, they affect many biological functions and show distinct antiviral activities (Gibbert et al., 2013). Many interferon genes belonging to different classes have been cloned and expressed in both prokaryotic and eukaryotic hosts. Among these INFs types are from human, camel, pig, cat, horse, turkey, goose, zebra fish, and Atlantic salmon (Srikanth et al., 2019; Abdel-Fattah et al., 2019; Barathiraja et al., 2018; Wang et al., 2020; Steinbach et al., 2002; Suresh et al., 1995; Tian et al., 2014; Altmann et al., 2003; Guo et al., 2019; Robertsen et al., 2003). To the best of our knowledge, the IFN $\alpha$ from the Arabian one-humped camel, Camelus dromedarius, has not been reported yet. This camel is the most important animals in the Arabian Peninsula, for its high cultural and economic value beside the recent increasing research interest (Al-Swailem et al., 2010; Ataya et al., 2014; Malik et al., 2018). The aim of the present study was to clone, express, purify, and characterize IFN $\alpha$ found in the liver of $C$. dromedarius.

\section{MATERIALS AND METHODS}

\section{Chemicals and reagents}

Chemicals and reagents used in this study were chromatographic or molecular biology grade as appropriate. Water was either de-ionized or milli-Q-grade.

Tissue collection and total RNA isolation and purification

Liver tissue samples ( $1 \mathrm{~g})$ from adult male C. dromedarius were collected immediately after scarification (The Northern Riyadh Slaughtering House, Riyadh, Saudi Arabia) submerged in $5 \mathrm{~mL}$ of RNA later solution (Ambion, Courtabeuf, France), and kept at 4 ${ }^{\circ} \mathrm{C}$, overnight; thereafter samples were kept at $-80{ }^{\circ} \mathrm{C}$. Total RNA was isolated and purified from $100 \mathrm{mg}$ of liver tissue using the RNeasy Mini Kit (Qiagen, Cat\#80204, Ambion, Courtabeuf, France) with a DNase digestion step following the manufacturer's protocol. Liver tissue was homogenized in $1.0 \mathrm{~mL}$ of RLT lysis solution containing $1 \%$ 2-mercaptoethanol using a rotor-stator homogenizer (Medic Tools, Switzerland). The total RNA was eluted by $100 \mu \mathrm{L}$ nuclease free water and its concentration, purity, and integrity were determined using the Agilent 2100 Bioanalyzer System and Agilent total RNA analysis kit, according to the manufacturer's protocols (Agilent Technologies, Waldbronn, Germany). Purified RNA samples with an RNA integrity number in the 7-10 range were used for first strand cDNA synthesis.
Synthesis of first strand cDNA and isolation of $\mathrm{C}$. dromedarius IFNa gene

The first strand cDNA was synthesized from 2 micrograms of total RNA following the manufacturer's protocol of the ImProm-II Reverse Transcription System (A3800, Promega, Madison, USA). The full-length $C$. dromedarius IFN $\alpha$ cDNA was obtained by PCR in a final volume of $50 \mu \mathrm{L}$, consisting of $25 \mu \mathrm{L} 2 \mathrm{X}$ high-fidelity master mix (GE Healthcare, USA), $3 \mu \mathrm{L}$ (30 pmol) each of IFN $\alpha$ forward primer containing an EcoRI restriction site (5'-GAATTC ATGTCCCCAGTGGCTCGACC-3') and reverse primer containing a HindIII restriction site (5'-AAGCTTTCTTTCTTGCAAGTGTCTCGC-3'), and $5 \mu \mathrm{L}$ cDNA. Amplification was performed using the following cycling conditions; 1 cycle at $95^{\circ} \mathrm{C}$ for $5 \mathrm{~min}$, followed by 30 cycles at $95^{\circ} \mathrm{C}$ for $30 \mathrm{~s}, 55^{\circ} \mathrm{C}$ for $30 \mathrm{~s}$, and $72{ }^{\circ} \mathrm{C}$ for $1 \mathrm{~min}$. A final extension step was carried out at $72^{\circ} \mathrm{C}$ for $5 \mathrm{~min}$. The PCR products were resolved on a $1.5 \%$ agarose gel in TEA buffer, stained and visualized with $0.5 \mu \mathrm{g} / \mathrm{mL}$ ethidium bromide and UV light. The separated bands of the amplified gene of expected size were cut from the gel and purified using the QiAquick gel extraction kit (Qiagen, Cat \# 28706, Ambion, Courtabeuf, France).

\section{Cloning and sequencing of full-length IFNa cDNA}

The plasmid cloning pGEM ${ }^{\circledR}-\mathrm{T}$ Easy vector (Promega, Cat \# A1360, Madison, USA) was used to clone the purified PCR product corresponding to IFN $\alpha$ cDNA to facilitate sequencing and sub-cloning into the pET28a (+) expression vector. The ligation reaction was using $4 \mu \mathrm{L}$ of PCR product, $1 \mu \mathrm{L}$ (50 ng) of pGEM $^{\circledR}$-TEasy vector, $1 \mu \mathrm{L}$ of $10 \mathrm{X}$ ligase buffer, and $1 \mathrm{U}$ of ligase enzyme and $3 \mu \mathrm{L}$ nuclease free water to a final volume of $10 \mu \mathrm{L}$. Reaction tubes were incubated at $16{ }^{\circ} \mathrm{C}$ for $16 \mathrm{~h}$, and $5 \mu \mathrm{L}$ from the ligation mixure was used to transform E. coli JM109 competent cells, according to the previously published methods of Sambrook et al. (1989). Screening was carried out on selective LB/ isopropyl$\beta$-D-1-thiogalactopyranoside (IPTG)/X-gal/ampicillin/ agar plates. Recombinant plasmids were purified from selected mostly white colonies using the PureYield Plasmid Miniprep System (Promega, Cat \#A1222, Madison, USA) and the cloned insert was sequenced according to the methods of Sanger et al. (1977) using the T7 (5'-TAATACGACTCACTATAGGG-3') and SP6 (5'-TATTTAGGTGACACTATAG-3') sequencing primers. Sequence analysis was carried out using the DNAStar, BioEdit, and ClustalW programs.

Phylogenetic tree and structural modeling analysis A phylogenetic tree was constructed according to the 
methods of Dereeper et al. (2008), using the Phylogeny. fr software (http://www.phylogeny.fr). The nucleotide and protein sequences for $C$. dromedarius IFN $\alpha$ cDNA were analyzed using the basic local alignment search tool (BLAST) programs BLASTn and BLASTp (http://www. ncbi.nlm.nih.gov), respectively, and multiple sequence alignments were carried out using the ClustalW, BioEdit, DNAStar, and Jalview programs. The translated amino acid sequence from the cDNA sequence was obtained using the translation tool on the ExPasy server (http://web. expasy.org/translate/). The protein structure prediction was obtained by submitting and amino acid sequence to the Swiss-Model server, and the structural data were analyzed using the PDB viewer program. Finally, the predicted 3D structure model of IFN $\alpha$ was built based on multiple threading alignments using the local threading meta-server (LOMET) and iterative TASSER assembly simulation (Ortiz, et al., 2002; Roy et al., 2010).

\section{Subcloning of IFNa gene into pET-28a (+) expression vector}

The IFNa cDNA insert was liberated from the pGEM-T-Easy vector using 2 units each of EcoRI and HindIII restriction enzymes and the appropriate buffer according to the methods of Sambrook et al. (1989) and purified after electrophoresis from the agarose gel using the QIAquick Gel Extraction Kit (Qiagen, Cat \# 28706, Ambion, Courtabeuf, France). The purified IFN $\alpha$ gene was ligated with pET-28a $(+)$ expression vector cut with the same enzymes as previously described. Subsequently, $5 \mu \mathrm{L}$ of the ligation reaction was used to transform $E$. coli BL21(DE3) pLysS (Promega, Cat. \# P9801, USA) competent cells, according to the methods of Sambrook et al. (1989). Recombinant E. coli BL21(DE3) pLysS harboring the pET-28a $(+)$ vector were screened for on selective LB/IPTG/X-gal/kanamycin/agar plates and by using the colony PCR strategy utilizing the IFN $\alpha$ genespecific primers.

Expression of C. dromedarius IFNa cDNA in E. coli BL21(DE3) pLysS

E. coli $\mathrm{BL} 21(\mathrm{DE} 3)$ pLysS containing the recombinant pET28a $(+)$ plasmid were used to inoculate one liter of LB medium supplemented with $34 \mu \mathrm{g} / \mathrm{mL}$ kanamycin and incubated at $37^{\circ} \mathrm{C}$ for $4 \mathrm{~h}$ with shaking at $250 \mathrm{rpm}$. The induction of IFN $\alpha$ expression was initiated from 0.6 optical density culture at $600 \mathrm{~nm}$ by the addition of $1 \mathrm{mM}$ IPTG and kept for $5 \mathrm{~h}$ incubation at $37^{\circ} \mathrm{C}$ under continuous shaking. The bacterial cells were harvested by centrifugation at $8000 \mathrm{rpm}$ for $20 \mathrm{~min}$ at $4^{\circ} \mathrm{C}$ and the biomass was re-suspended in $10 \mathrm{~mL}$ of $0.1 \mathrm{M}$ potassium phosphate buffer, $\mathrm{pH} 7.5$, containing $50 \%$ glycerol. The bacterial cell suspension was then ultrasonicated on an ice-bath using 4 x 30-s pulses, and the clear supernatant containing the expressed protein was collected from the cell debris by centrifugation at $10,000 \mathrm{rpm}$ for $10 \mathrm{~min}$ at $4^{\circ} \mathrm{C}$.

\section{Protein determination}

Protein concentration was determined using Coomassie brilliant blue G-250 (1976), using $0.5 \mathrm{mg} / \mathrm{mL}$ of bovine serum albumin as a standard.

\section{Sodium dodecyl sulfate gel electrophoresis (SDS-PAGE)} and western blotting analysis

Expression of recombinant $C$. dromedarius IFN $\alpha$ in E. coli was evaluated by performing a $12 \%$ SDS-PAGE according to the methods of Laemmli (1970). After electrophoresis, the gel was stained with Coomassie Brilliant Blue R-250 followed by de-staining in a solution of $10 \%(\mathrm{v} / \mathrm{v})$ methanol and $10 \%(\mathrm{v} / \mathrm{v})$ acetic acid. Recombinant $C$. dromedarius IFNa protein was detected by western blotting using $6 \mathrm{x}$-His-Tag monoclonal antibody (His. H8, Cat\# MA1-21315, Thermo Fisher Scientific) at a 1:1000 dilution according to the methods of Towbin et al. (1979). Goat anti-mouse IgG labeled with horse radish peroxidase (Invitrogen Cat\# G-21040) secondary antibody was used at a dilution of 1:2000. The membrane was developed using the chromogenic substrate 3, 3', 5, 5'- tetramethylbenzidine liquid substrate system (SigmaAldrich, Cat\# T0565).

\section{Solubilization and refolding of C. dromedarius recombinant IFNa inclusion bodies}

The inclusion bodies present in the pellets after ultrasonication were recovered by centrifugation and washed three times in $20 \mathrm{mM}$ Tris- $\mathrm{HCl}, \mathrm{pH}$ 8.0. Then, they were solubilized by continuous stirring on an ice-bath with denaturation buffer containing $50 \mathrm{mM} \mathrm{M}$ Tris- $\mathrm{HCl}(\mathrm{pH}$ 8.0), $0.3 \mathrm{M} \mathrm{NaCl}$, and $2 \%$ SDS until the solution became clear and the product was kept at $4{ }^{\circ} \mathrm{C}$ overnight. The excess precipitated SDS was eliminated by centrifugation for $10 \mathrm{~min}$ at $10,000 \mathrm{rpm}$ and $4^{\circ} \mathrm{C}$. Subsequently, 400 $\mathrm{mM}$ of $\mathrm{KCl}$ was added to the supernatant and the solution was kept at $4^{\circ} \mathrm{C}$ overnight. Thereafter, the precipitate was discarded by centrifugation and the clear supernatant was dialyzed overnight against $50 \mathrm{mM}$ potassium phosphate buffer ( $\mathrm{pH} 7.5)$ and applied to a nickel affinity column (He and Ohnishi, 2017; Bornhorst and Falke, 2000).

Single step affinity purification of C. dromedarius recombinant IFN $\alpha$

Recombinant IFN $\alpha$ in the solubilized inclusion bodies was purified using a single-step High-Select High Flow 
nickel affinity chromatography column $(1.0 \mathrm{~cm} \times 1.0 \mathrm{~cm})$ (Sigma-Aldrich, Cat. \# H0537) previously washed with 5 bed volumes of de-ionized water, and equilibrated with 5-bed volumes of $50 \mathrm{mM}$ potassium phosphate buffer $(\mathrm{pH}$ 7.5) containing $20 \mathrm{mM}$ imidazole. A solution of solubilized inclusion bodies was applied to the column and the column was washed with 5-bed volumes of equilibration buffer. The bound recombinant IFN $\alpha$ was eluted with $50 \mathrm{mM}$ potassium phosphate buffer ( $\mathrm{pH} 7.5)$ containing $500 \mathrm{mM}$ imidazole. The collected fractions were measured at 280 $\mathrm{nm}$ against blank buffer solution containing appropriate concentrations of imidazole and the fractions presented in the second peak were pooled together and dialyzed overnight against $50 \mathrm{mM}$ potassium phosphate buffer $(\mathrm{pH}$ 7.5). The purity of the dialyzed recombinant IFN $\alpha$ was evaluated by performing $12 \%$ SDS-PAGE.

Cytotoxicity of recombinant $\mathrm{C}$. dromedarius IFNa on a breast cancer cell line

Cells from the MDA-MB-231 triple negative breast cancer line, obtained from ATCC, were cultured in Dulbecco's Modified Eagle's Medium supplemented with 10\% fetal bovine serum (Sigma-Aldrich Co., USA), $100 \mathrm{U} / \mathrm{mL}$ penicillin, and $100 \mathrm{mg} / \mathrm{mL}$ streptomycin, and maintained in $5 \% \mathrm{CO}_{2}$ at $37^{\circ} \mathrm{C}$. An MTT assay was performed by seeding the cells in 96 well plates at a density of 15,000 cells/well and after an incubation period of $24 \mathrm{~h}$, the cells were treated with varied concentrations of IFN $\alpha$ protein; control cells received culturing medium in phosphate buffer saline (PBS) solution. A subsequent incubation was carried out for $24 \mathrm{~h}$ after which, cells were washed twice with PBS followed by the addition of 3-(4,5-dimethyl-2-thiazolyl)-2,5 diphenyl-2H-tetrazolium bromide (MTT) (Serva Co.) reagent to each well at a concentration of $10 \mu \mathrm{L}$ of $5 \mathrm{mg} / \mathrm{mL}$ in $100 \mu \mathrm{L}$ serum free medium. Incubation was continued for $4 \mathrm{~h}$ at $37^{\circ} \mathrm{C}$, following which the medium was discarded, $100 \mu \mathrm{L}$ of DMSO was added to each well, the plates were shaken for 10-15 $\mathrm{min}$, and the absorbance was measured at $490 \mathrm{~nm}$ (Abdel-Fattah et al., 2019).

\section{Statistical analysis}

GraphPad Prism 6.0 Software was used to perform statistical analyses. One way or two way ANOVAs (followed by Tukey or Sidak's posttest) were used where appropriate. Data are presented as the mean \pm SEM or \pm SD from at least two independent experiments.

\section{RESULTS AND DISCUSSION}

Nucleotide sequence analysis of C. dromedarius IFN $\alpha$

To date, most information about type I IFNs has originated from studies on IFNs from other species such as human, red-crowned crane, equine, porcine, goose, salmon, turkey, and cattle (Srikanth et al., 2019; Tian et al., 2014; Steinbach et al., 2002; Li et al., 2019; Guo et al., 2019; Robertsen et al., 2003; Suresh et al., 1995; Barathiraja et al., 2018), and limited data are available about IFNs from $C$. dromedarius, the one-humped Arabian camel (Abdel-Fattah et al., 2019). In the present study, the full-length cDNA open reading frame of $C$. dromedarius IFN $\alpha$ was isolated by reverse transcriptionPCR using gene specific primers designed from the available expressed sequence tag camel genome project database (http://camel.Kacst.edu.sa/). The PCR product corresponding to 561 nucleotides represents the entire open reading frame of $C$. dromedarius IFN $\alpha$ (Fig. 1). The purified PCR product was cloned first into the pGEM-TEasy vector and the cDNA insert was sequenced using T7 and SP6 primers. The generated nucleotide sequence was deposited in the GenBank database under the accession number MK055340. The nucleotide sequence of the putative $C$. dromedarius IFN $\alpha$ gene has a statistically significant similarity score to numerous IFN $\alpha$ genes from other species (Table I). To determine the relatedness of C. dromedarius IFN $\alpha$ with known amino acid sequences from other species available in the GenBank database, a multiple sequence alignment was conducted (Fig. 2). The percentage identity of $C$. dromedarius IFN $\alpha$ with other species was $98 \%$ for Camelus ferus (GenBank accession \# XP_014408676), 73\% for Equus asinus (XP_014686765), $70 \%$ for Sus scrofa (NP_001158321), and $6 \overline{6} \%$ for Homo sapiens (NP_002166). A phylogenetic tree constructed from

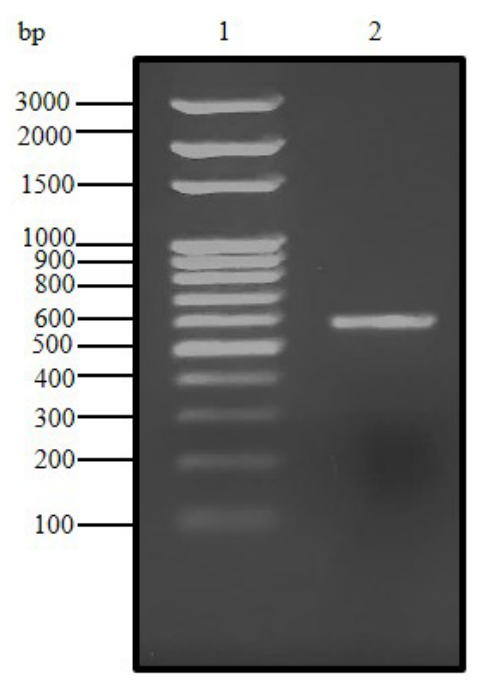

Fig. 1. Agarose gel (1.5\%) electrophoresis of PCR product for $C$. dromedarius IFNa gene (Lane 2). Lane 1 represents 100 base pair DNA ladder. 


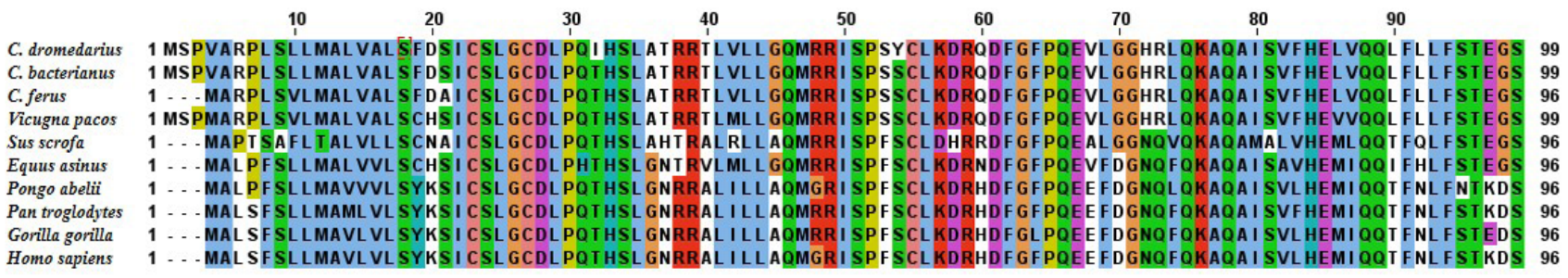

100

110

120

130

140

150

160

170

180

190

C. dromedarius 100 SA AWEDSLLHRL CT GLDQQL TELEACPKQEAE LQGRLLL NEDP I LAVRRYFHRI TLYLQEKKYSPC AWEI VRAEVMRSF SS ARHLQER - . - . -

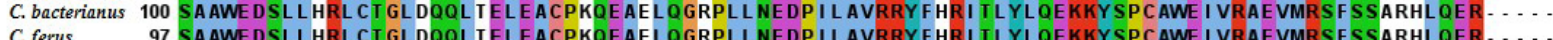

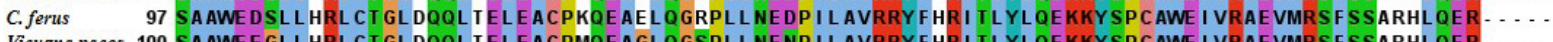

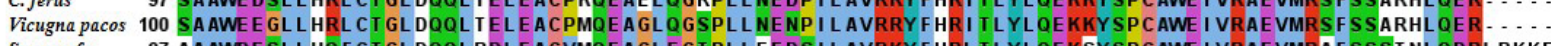

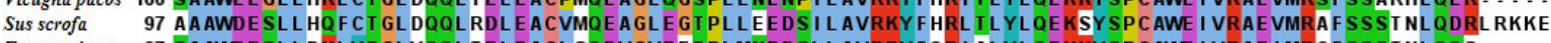

Equus asinus 97 SAAWDE SLLDKLYT GLYQQL TELEACL SQEVGVEET PL MNE DSLLAVRRY FQR I ALYLQEKKY PCAWE I VRAE I MRCF SSST NLQQS

Pongo abelii 97 SAAWEQSLLEKF TIEL NQQL NDLEACMI QEVGVEE TPL MNVDS I LAVKKYFQRI TL YL TEKKY SPCAWE VVRAE I MRSF SL SKT FQERLRRKE

Pan troglodytes 97 SAAWDETLLDKFYIEL FQQL NDLEACVI QEVGVEE T PLMNEDS I LAVRKYFQR I TLYLME KKY SPCAWEVVRAE I MRSF SF ST NL QKRLRRKD

Gorilla gorilla 97 SAAWEQSLLEKFSTELYQQLNNLEACVI QEVGVEETPLMNEDS I LAVRKYFQRI TLYL TEKKYSPCAWEVVRAE I MRSL SF ST NL QKRLRRKD

Homo sapiens 97 SATWEQSLLEKF STELNQQL NDLEACVI QEVGVEE TPLMNVDS I LAVKKYFQRI TLYL TEKKYSPCAWEVVRAE I MRSF SL SKI FQERLRRKE

Fig. 2. Alignment of the deduced amino acid sequence of $C$. dromedrius IFN $\alpha$ with IFN $\alpha$ from other species.

the amino acid sequences of the predicted IFN $\alpha$ proteins deposited in GenBank indicated that $C$. dromedarius IFN $\alpha$ diverged along a separate evolutionary path that is distinct from other ungulates and mammalian species including human (Fig. 3).

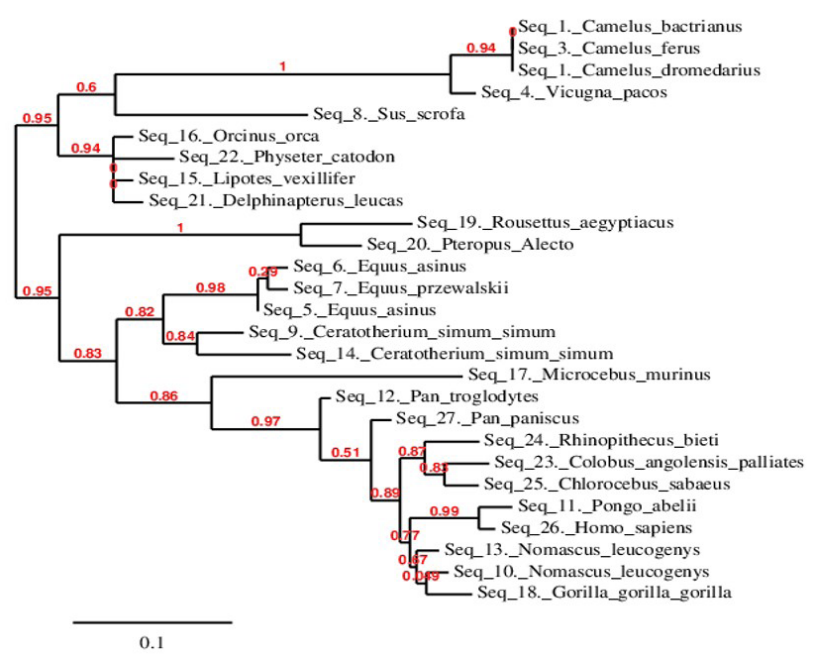

Fig. 3. Phylogenetic relationship of $C$. dromedarius IFN $\alpha$ and sequences from other species. Maximum likelihood tree based on complete coding sequences deposited in GenBank. Values at nodes are bootstrap $\geq 50 \%$, obtained from 1000 re-samplings of the data.

\section{Structural annotations and predicted 3D structure}

The primary structure and protein motif secondary structural annotation for $C$. dromedarius IFN $\alpha$ are shown in Figures 4 and 5. The $C$. dromedarius IFN $\alpha$ nucleotides and deduced amino acid sequence showed an open reading frame consisting of $564 \mathrm{bp}$ and 187 amino acid residues with a molecular weight of $21.339 \mathrm{kDa}$. The predicted isoelectric point was determined to be 7.67 using a computer algorithm. Analysis of secondary structural elements of $C$. dromedarius IFNa revealed the presence of some conserved

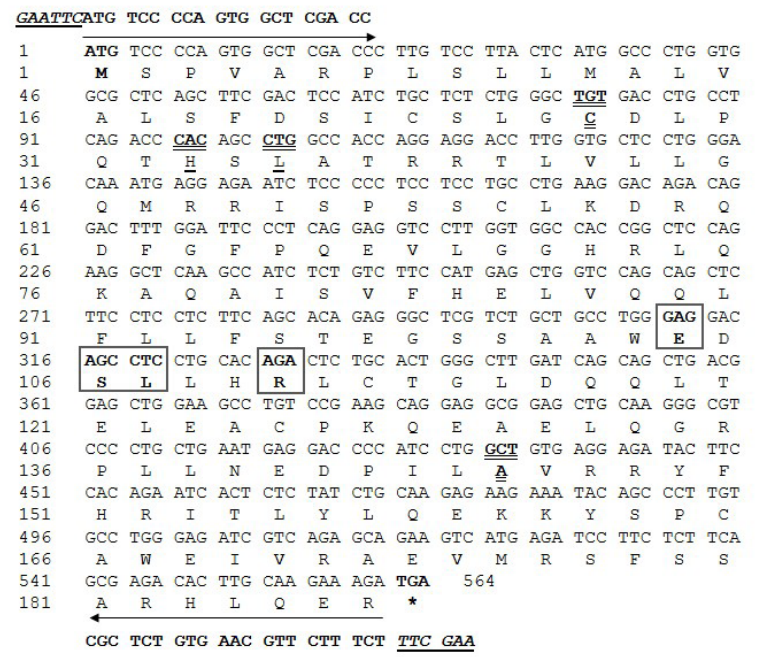

Fig. 4. Nucleotide and deduced amino acid encoding region of $C$. dromedarius IFNa. Important amino acid residues and regions include: residues that may contact $\mathrm{N}$-Acetyl-2-Deoxy-are indicated by the box; residues that may contact an $\mathrm{SO}_{4}$ ion are indicated in bold underline; residues that may contact $\mathrm{Zn}^{2+}$ are indicated by bold double underline, conserved amino acid residues in the IFN $\alpha$ protein are indicated by bold dashed underline, residues involved in IFNAR-1 binding are indicated with the circle, and residues involved in IFNAR-2 binding are indicated by the bold dashed box. Arrows indicate the location of the forward and reverse primers with restriction enzyme sites presented in bold underline italics. 
Table I. Homology of the deduced amino acids of $C$. dromedarius interferon $\alpha$ with other species.

\begin{tabular}{lll}
\hline Animal species & Accession no. & $\begin{array}{l}\text { \% Iden- } \\
\text { tity }\end{array}$ \\
\hline Camelus bacterianus & XP_010944312 & 100 \\
Camelus ferus & XP_014408676 & 98 \\
Vicugna pacos & XP_015098135 & 94 \\
Equus asinus & XP_014686765 & 73 \\
Equus przewalskii & XP_008530158 & 72 \\
Sus scrofa & NP_001158321 & 70 \\
Ceratotherium simum simum & XP_004436883 & 70 \\
Balaenoptera acutorostrata scammoni_007176876 & 74 \\
Orcinus orca & XP_0071275088 & 74 \\
Nomascus leucogenys & XP_00427 & XP_003260419 69 \\
Pongo abelii & XP_002819800 & 68 \\
Microcebus murinus & XP_012625263 68 \\
Gorilla gorilla gorilla & XP_004047912 & 68 \\
Rousettus aegyptiacus & XP_016015901 67 \\
Homo sapiens & NP_002166 & 66 \\
\hline
\end{tabular}

features. The first feature is the presence of 18 amino acid residues $\left(\mathrm{Q}^{31,46,118}, \mathrm{~T}^{32,114,120}, \mathrm{R}^{38,}{ }^{39}, \mathrm{G}^{45}, \mathrm{~W}^{103}, \mathrm{E}^{104,121}\right.$, $\left.\mathrm{S}^{106}, \mathrm{~L}^{107}, \mathrm{H}^{109}, \mathrm{R}^{110}, \mathrm{D}^{117}, \mathrm{~A}^{124}\right)$ that represent the putative IFNAR-1 binding site, localized in helices A and $\mathrm{C}$ (Fig. 5), which is critical for receptor recognition and biological activity. The second conserved feature is the presence of a putative IFNAR-2 binding site as a part of the AB loop helix D and DE loop, which is represented by 27 amino acid residues $\left(\mathrm{L}^{56,74,144,155,} \mathrm{~K}^{57,160},{ }^{161}, \mathrm{D}^{58,61}, \mathrm{R}^{59,73,147,148,152}\right.$, $\left.\mathrm{Q}^{60,66,158}, \mathrm{~F}^{62}, \mathrm{G}^{63}, \mathrm{P}^{65}, \mathrm{E}^{67,159}, \mathrm{~A}^{145}, \mathrm{H}^{151}, \mathrm{~T}^{154}, \mathrm{E}^{159}, \mathrm{Y}^{162}, \mathrm{~S}^{163}\right)$. Analysis of glycosylation sites in $C$. dromedarius IFN $\alpha$ led to the prediction of one potential glycation site not occurring within the common Asn-Xaa-Ser/Thr glycation signal and this site is represented by the conserved $\mathrm{E}^{104}$ residue (Fig. 5). Glycosylation sites are believed to play an important role in regulating protein solubility, folding, oligomerization, and stability as well as protection against proteolytic degradation (Samudzi et al., 1991). Other conserved amino acids residues involved in the binding

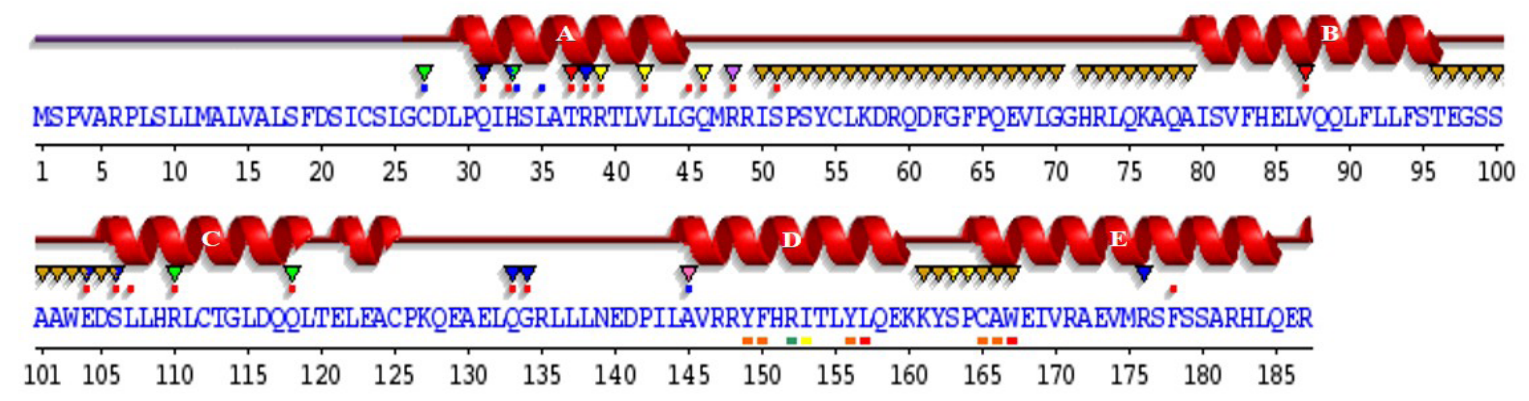

Fig. 5. Sequence annotations for $C$. dromedarius IFN $\alpha$ showing the location of $\alpha$-helices and residues contacting ligand and ions. Secondary structure by homology ( ( to ions $(*)$.
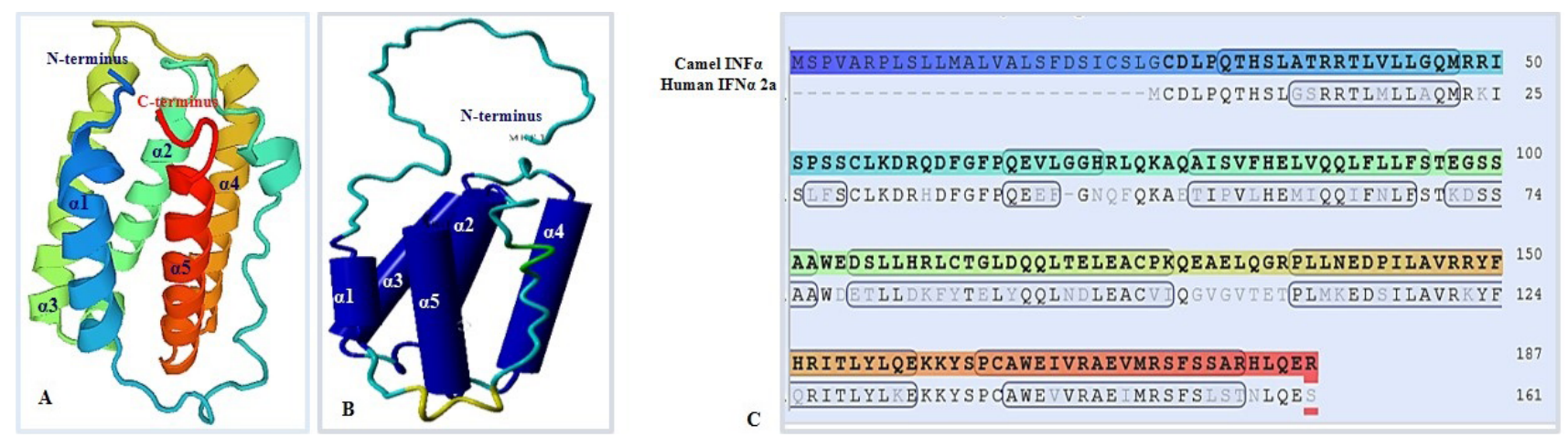

Fig. 6. Predicted 3D structure of C. dromedarius IFN $\alpha$ protein shows the overall secondary structure in ribbon form (A) and cartoon form (B). Alpha helices are labeled from $\alpha 1$ to $\alpha 5$. (C) Model-template alignment of amino acid residues of C. dromedarius IFN $\alpha$ and Homo sapiens IFN $\alpha 2$ a. Components of the secondary structure are shown in blue ( $\alpha$ helices) and brown (coils). Identical amino acid residues are shown in bold black. 
of different ligands and DNA are shown in Table II. The predicted three dimensional structure of $C$. dromedarius IFN $\alpha$ showed that the secondary structure of the protein consisted of five alpha helices labeled from $\mathrm{A}$ to $\mathrm{E}$ as shown in Figure 6A and B. Composition of the secondary structure revealed $65.78 \% \alpha$-helices and $34.22 \%$ coils and turns. Analysis of the 3D structure of C. dromedarius IFNa revealed that the overall folding was similar to that of $H$. sapiens IFN $\alpha 2 \mathrm{a}$ and the percent similarity and conservation in the secondary structure location was $64.6 \%$ (Fig. 6C).

Expression, solubilization, and in vitro refolding of IFNa

C. dromedarius IFN $\alpha$ was overexpressed in E. coli cells upon induction with $1 \mathrm{mM}$ IPTG and appeared in insoluble inclusion bodies that were easily separated upon sonication and centrifugation at $12,000 \mathrm{rpm}$ for 10 min at $4{ }^{\circ} \mathrm{C}$, leaving behind a supernatant devoid of IFN $\alpha$ protein as shown in Figure 7A. Western blotting analysis for recombinant $C$. dromedarius IFN $\alpha$ inclusion bodies protein with $6 \mathrm{x}-\mathrm{His}-\mathrm{Tag}$ monoclonal antibody revealed an immune-reacted band at $22.5 \mathrm{kDa}$ (Fig. 7B and C). To recover soluble IFN $\alpha$ from the inclusion bodies, the $\mathrm{SDS} / \mathrm{KCl}$ method was performed (Fig. 8A Lanes 3-7). Recovered, solubilized, and refolded IFN $\alpha$ inclusion bodies were then subjected to nickel-affinity chromatography and bound IFN $\alpha$ was eluted using $500 \mathrm{mM}$ imidazole (Fig. $8 \mathrm{~B})$. The purified IFN $\alpha$ showed a unique single protein band at $22.5 \mathrm{kDa}$ (Fig. 8C).

Cytotoxicity of C. dromedarius $I F N \alpha$ on a breast cancer cell line

IFN $\alpha$ has shown potential beneficial effects in various types of tumours such as hepatocellular carcinoma
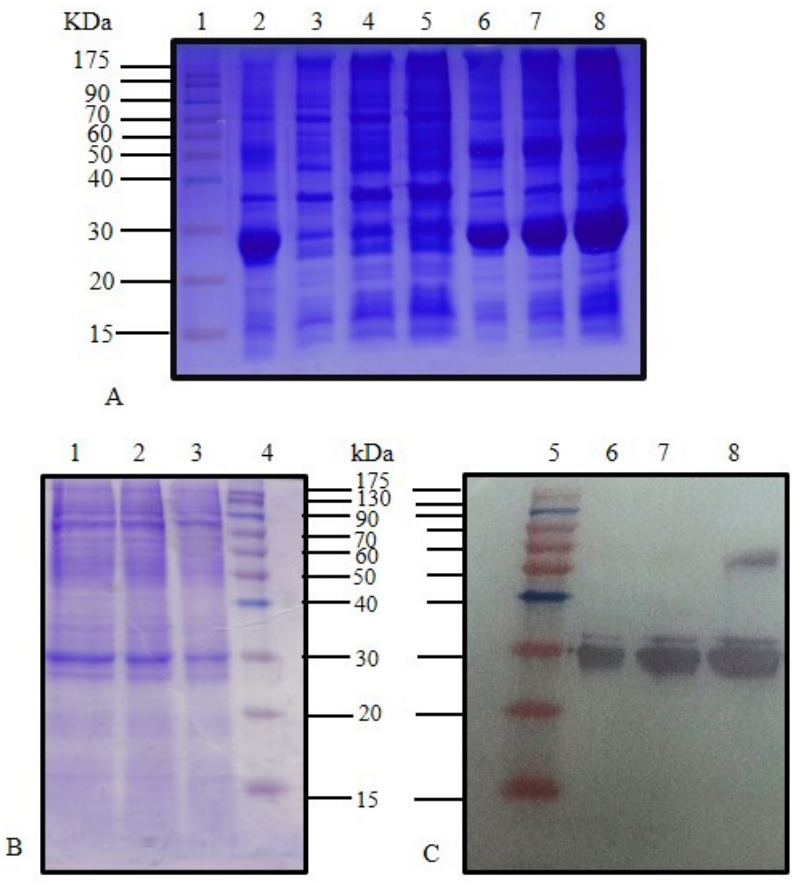

Fig. 7. SDS-PAGE (12\%) for IPTG induced E. coli BL21(DE3) pLysS pET28 a (+) harboring $C$. dromedarius IFN $\alpha$ cDNA (Lane 2), IPTG induced culture supernatant (Lanes 3-5), and IPTG induced culture inclusion bodies (Lanes 6-8). (B) SDS-PAGE (12\%) for IPTG induced culture (Lanes 1-3) and western blotting analysis with 6x-His-Tag monoclonal antibody (1:1000 dilution) for IPTG induced culture (Lanes 6-8). Lanes 1 (Panel A), 4 (Panel B) and 5 (Panel C) represent pre-stained molecular weight protein markers.

Table II. Conserved amino acid residues of $C$. dromedarius interferon $\alpha$ involved in different ligands and metal ions binding.

\begin{tabular}{|c|c|}
\hline Annotation features & Amino acid residues \\
\hline \multicolumn{2}{|l|}{ Contact(s) to ligands } \\
\hline \multicolumn{2}{|l|}{ - 1,2-Ethanediol } \\
\hline - Acetate ion & $\mathrm{His}^{33}$ \\
\hline $\begin{array}{l}\text { - 4-(2-Hydroxyethyl)-1-Piperazine ethanesulfonic } \\
\text { acid }\end{array}$ & $\mathrm{Arg}^{48}, \mathrm{Ser}^{51}$ \\
\hline - Sulfate ion & $\mathrm{Gln}^{31}, \operatorname{Arg}^{38}, \mathrm{Arg}^{39}, \mathrm{Val}^{42}, \mathrm{Gln}^{46}$ \\
\hline - Beta-D-Glucose, G6D=6-Deoxy-Alpha-D-Glucose & \\
\hline Contact(s) to metals & Glu $^{104}$, Ser $^{106}$, Leu $^{107}, \operatorname{Arg}^{110}$ \\
\hline \multicolumn{2}{|l|}{-Nickel (ii) ion } \\
\hline -Zinc ion & $\mathrm{Cys}^{27}, \mathrm{His}^{33}$ \\
\hline \multirow[t]{2}{*}{-Chloride ion } & $\mathrm{His}^{33}, \mathrm{Ala}^{145}$ \\
\hline & $\mathrm{His}^{33}, \mathrm{Leu}^{35}$ \\
\hline \multicolumn{2}{|l|}{ Nucleic acids binding residues } \\
\hline & $\begin{array}{l}\mathrm{Leu}^{35,41}, \mathrm{Ala}^{36,124}, \mathrm{Arg}^{38,39}, \mathrm{Val}^{41}, \mathrm{His}^{109,183}, \mathrm{Thr}^{113,120}, \mathrm{Gly}^{114}, \mathrm{Gln}^{117}, \mathrm{Glu}^{121,186} \text {, } \\
\text { Ser }^{179}\end{array}$ \\
\hline
\end{tabular}



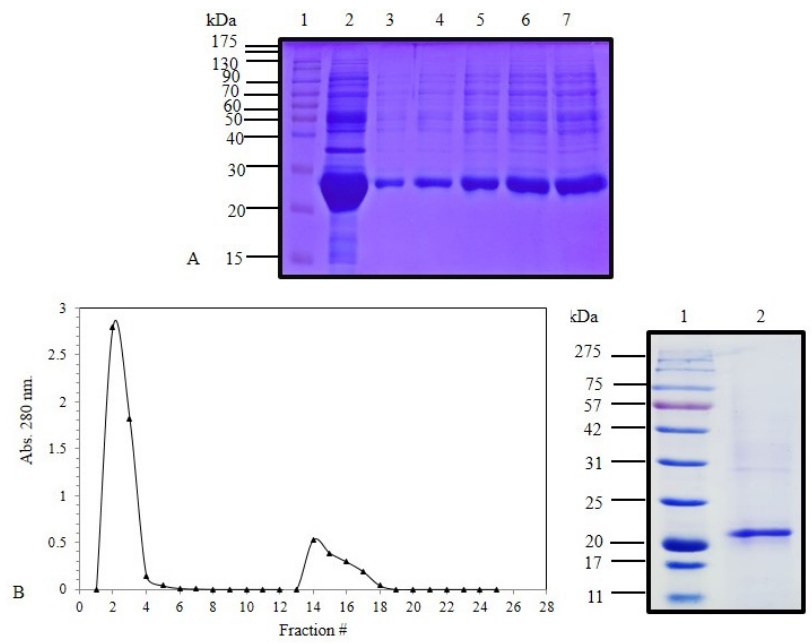

Fig. 8. (A) SDS-PAGE (12\%) for IPTG induced E. coli BL21(DE3) pLysS pET 28 a (+) harboring IFN $\alpha$ cDNA inclusion bodies protein (Lane 2) and solubilized IFNa inclusion bodies (Lanes 3-7). (B) Elution profile of $C$. dromedarius IFNa after nickel affinity chromatography. Column flow rate was adjusted to be $3 \mathrm{~mL} / 5 \mathrm{~min}$. (C) SDSPAGE (12\%) for nickel affinity purified camel IFN $\alpha$ protein (Lane 2). Lanes 1 in Panel A and B represent pre-stained molecular weight protein markers.

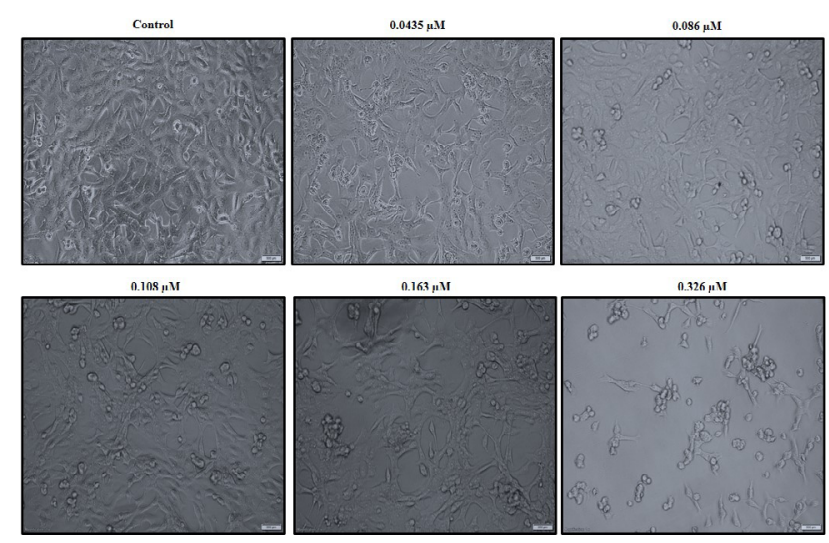

Fig. 9. C. dromedarius IFN $\alpha$ alters the morphology of the MDA-MB-231 triple negative breast cancer cell line in a dose dependent manner. Cells were treated with varied concentrations of purified recombinant $C$. dromedarius IFN $\alpha(0.0435-0.326 \mu \mathrm{M})$ for $24 \mathrm{~h}$. Cells exhibited morphological changes indicated by shrinkage, detachment from the substratum, and rounding up as the concentration of IFN $\alpha$ protein increased compared with that observed for the control untreated cells (C). Magnification was 40X.

(Zhang et al., 2019), ovarian cancer (Green et al., 2016), and head and neck squamous cell carcinoma (Yang et al. 2019). However, the effects of recombinant $C$. dromedarius IFN $\alpha$ on human cancer cells have not been fully elucidated.
To study the effects of $C$. dromedarius IFN $\alpha$ on the MDAMB-231 triple negative breast cancer cell line, cells were treated with varied concentrations of the purified recombinant protein and the morphology and viability of the cells were examined. The morphological changes observed after $24 \mathrm{~h}$ of treatment are shown in Figure 9.

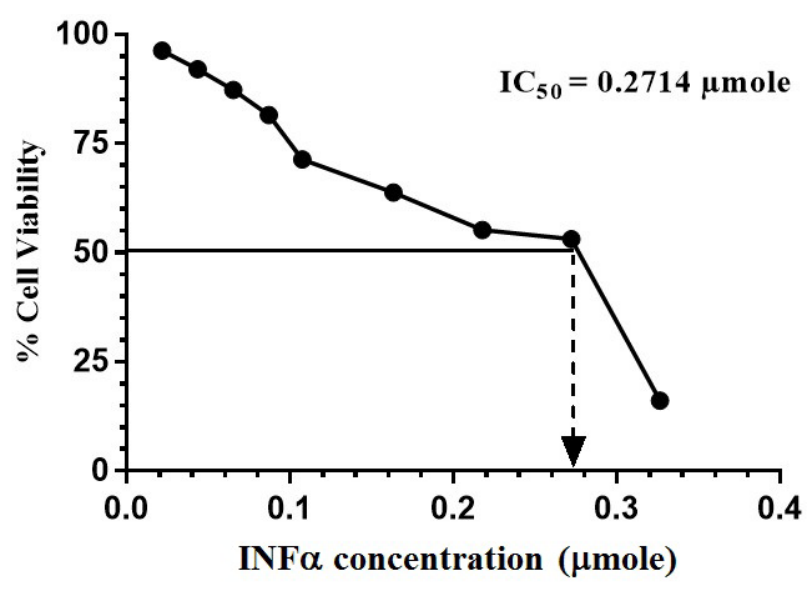

Fig. 10. MTT assay was performed and the $\%$ cell viability was calculated compared to that of the control cells. GraphPad Prism 6 was used to calculate the $\mathrm{IC}_{50}$ of $C$. dromedarius IFN $\alpha$ protein.

Cells appeared rounded up, were easily detachable, and exhibited shrinkage and reduction in size as the concentrations of the recombinant protein increased compared with that of untreated control cells (Fig. 9) suggesting inhibition of cell viability. To investigate the effect of $C$. dromedarius IFNa protein on cell viability, MTT assays were performed. The results demonstrated that IFN $\alpha$ inhibits the viability of cells in a dose dependent manner and the IC50 was calculated as $0.2714 \mu$ mole (Fig. 10). Type I IFNs are among the most widely used human recombinant therapeutic proteins for the treatment of several cancers and various viral infections. In addition, within the 13 alpha subtypes, only IFN $\alpha 2 \mathrm{~A}$ (Roferon A) and IFN $\alpha 2 b$ (Intron A) have been approved by the FDA and marketed for therapeutic use. Since these proteins are not glycosylated, the biopharmaceutical industry is able to use $E$. coli as a host cell factory to produce them (Ghasriani et al., 2013).

In conclusion, in this study, we presented cloning, expression, in vitro re-folding, and characterization of a novel $C$. dromedarius IFNa protein. Additionally, cytotoxicity of the recombinant protein was addressed using a triple negative breast cancer cell line; however, further research is required to unravel the role of $C$. dromedarius IFN $\alpha$ as a potential anti-cancer agent. 


\section{Declarations of interest}

The authors declare that there is no conflict of interest for this article and there is no financial employment, consultancies, honoraria, stock ownership or options, expert testimony, grants or patents received or pending, royalties related to this manuscript. Moreover, the authors declare that this work has not been published nor simultaneously submitted for publication elsewhere. All authors agree to the submission of this manuscript.

\section{REFERENCES}

Abdel-Fattah, M., Saeed, H., El-Shennawy, L., Shalaby, M., Embaby, A., Ataya, F., Mahmoud, H. and Hussein, A., 2019. The Arabian camel, Camelus dromedarius interferon epsilon: Functional expression, in vitro refolding, purification and cytotoxicity on breast cancer cell lines. PLoS One, 14: e0213880. https://doi.org/10.1371/journal. pone. 0213880

Al-Swailem, A.M., Shehara, M.M., Adu-Duhier, F.M., Al-Yamani, E.J., Al-Busadah, K.A., Al-Arawi, M.S., Al-Khider, A.Y., Al-Muhaimeed, A.N., AlQahtani, F.H., Manee, M.M., Al-Shomrani, B.M., Al-Qhtani, S.M., Al-Harthi, A.S., Akdemir, K.C., Inan, M.S. and Otu. H.H., 2010. Sequencing, analysis and annotation of expressed sequence tags for Camelus dromedaries. PLoS One, 5: e10720. https://doi.org/10.1371/journal.pone.0010720

Altmann, S.M., Mellon, M.T., Distel, D.L. and Kin, C.H., 2003. Molecular and functional analysis of an interferon gene from the zebrafish, Danio rerio. J. Virol., 77: 1992-2002. https://doi.org/10.1128/ JVI.77.3.1992-2002.2003

Ataya, F.S., Al-Jafari, A.A., Daoud, M.S., Al-Hazzani, A.A., Shehata, A., Saeed, H.M. and Fouad, D., 2014. Genomics, phylogeny and in Silico analysis of mitochondrial glutathione Stransferase-Kappa from the camel Camelus dromedarius. Res. Vet. Sci., 97: 46-54. https://doi.org/10.1016/j. rvsc.2014.04.004

Baldo, B.A., 2014. Side effects of cytokines approved for therapy, Drug Saf., 37: 921-943. https://doi. org/10.1007/s40264-014-0226-Z

Barathiraja, S., Gangadhara, P.A.V., Umapathi, V., Dechamma, H.J. and Reddy, G.R., 2018. Expression and purification of biologically active bovine interferon $\lambda 3$ (IL28B) in Pichia pastoris. Protein Expr. Purif., 145: 14-18. https://doi.org/10.1016/j. pep.2017.12.007

Borish, L.C. and Steinke, J.W., 2003. Cytokines and chemokines. J. Allergy clin. Immunol., 111: S460-
S475. https://doi.org/10.1067/mai.2003.108

Bornhorst, J.A. and Falke, J.J., 2000. Purification of proteins using polyhistidine affinity tags. Methods Enzymol., 326: 245-254. https://doi.org/10.1016/ S0076-6879(00)26058-8

Bradford, M.M., 1976. A rapid and sensitive method for the quantitation of microgram quantities of protein utilizing the principle of protein-dye binding. Anal. Biochem., 72: 248-254. https://doi. org/10.1016/0003-2697(76)90527-3

Cooksley, W.G., 2004. The role of interferon therapy in hepatitis B. Med. Gen. Med., 6: 16.

Dereeper, A., Guignon, V., Blanc, G., Audic, S., Buffet, S., Chevenet, F., Dufayard, J-F., Guindon, S., Lefort, V., Lescot, M., Claverie, J-M. and Gascuel, O., 2008. Phylogeny.fr: Robust phylogenetic analysis for the non-specialist. J. Nucl. Acids Res., 36: W465-W469. https://doi.org/10.1093/nar/ gkn180

Ferrantini, M., Capone, I. and Belardelli, F., 2007. Interferon- $\alpha$ and cancer: Mechanism of action and new perspectives of clinical use. Biochimie, 89: 884893. https://doi.org/10.1016/j.biochi.2007.04.006

Fischer, C.D., Wachoski-Dark, G.L., Grant, D.M., Bramer, S.A. and Klein, C., 2018. Interferon epsilon is constitutively expressed in equine endometrium and up-regulated during the luteal phase. Anim. Reprod. Sci., 195: 38-43. https://doi.org/10.1016/j. anireprosci.2018.05.003

Ghasriani, H., Belcourt, P.J., Sauvé, S., Hodgson, D.J., Brochu, D., Gilbert, M. and Aubin, Y., 2013. A single $\mathrm{N}$-acetylglucosamine residue at threonine 106 modifies the dynamics and structure of Interferon $\alpha 2 \mathrm{a}$ around the glycosylation site. J. biol. Chem., 288: 247-254. https://doi.org/10.1074/jbc. M112.413252

Gibbert, K., Schlaak, J.F., Yang, D. and Dittmer, U., 2013. IFN-alpha subtypes: Distinct biological activities in anti-viral therapy. Br. J. Pharmacol., 168: 1048-1058. https://doi.org/10.1111/bph.12010

Green, D.S., Nunes, A.T., Annunziata, C.M. and Zoon, K.C., 2016. Monocyte and interferon based therapy for the treatment of ovarian cancer. Cytokine Growth Factor Rev., 29: 109-115. https://doi. org/10.1016/j.cytogfr.2016.02.006

Guo, Y., Xu, Y., Kang, X., Meng, C., Gu, D., Zhou, Y., Xiong, D., Geng, S., Jiao, X. and Pan, Z., 2019. Molecular cloning and functional analysis of TRAF6 from Yangzhou great white goose Anser anser. Dev. comp. Immunol., 101: 103435. https:// doi.org/10.1016/j.dci.2019.103435

He, C. and Ohnishi, K., 2017. Efficient renaturation 
of inclusion body proteins denatured by SDS. Biochem. biophys. Res. Commun., 490: 1250-1253. https://doi.org/10.1016/j.bbrc.2017.07.003

Isaacs, A. and Lindemann, J., 1957. Virus interference. I. The interferon. Proc. R. Soc. Lond. B. Biol. Sci., 147: 258-267. https://doi.org/10.1098/ rspb.1957.0048

Kaplan, A., Lee, M.W., Wolf, A.J., Limon, J.J., Becker, C.A., Ding, M., Murali, R., Lee, E.Y., Wong, G.C.L. and Underhill, D.M., 2017. Direct Antimicrobial Activity of IFN- $\beta$. J. Immunol., 198: 4036-4045. https://doi.org/10.4049/jimmunol.1601226

Klotz, D., Baumgartner, W. and Gerhauser, I., 2017. Type I interferons in pathogenesis and treatment of canine diseases, Vet. Immunopathol., 191: 80-93. https://doi.org/10.1016/j.vetimm.2017.08.006

Laemmli, U.K., 1970. Cleavage of structural proteins during the assembly of the head of bacteriophage T4. Nature, 227: 680-685. https://doi. org/10.1038/227680a0

Li, S., Gong, M., Xie, Y., Shao, J., Zhao, F., Zhang, Y. and Chang, H., 2019. A novel type I interferon, interferon alphaomega shows antiviral activity against foot-and-mouth disease virus in vitro. Microb. Pathog., 127: 79-84. https://doi. org/10.1016/j.micpath.2018.11.040

Malik, A., Khan, J.M., Alamery, S.F., Fouad, D., Labrou, N.E., Daoud, M.S., Abdelkader, M.O. and Ataya, F.S., 2018. Monomeric Camelus dromedarius GSTM1 at low $\mathrm{pH}$ is structurally more thermostable than its native dimeric form. PLoS One, 13: e0205274. https://doi.org/10.1371/ journal.pone. 0205274

Meager, A., 2009. The interferons: Past, present and future, Dig. Liver Dis. 3, 3-8. Noël, N., Béatrice, B.J., Huot, N., Goujard, C., Lambotte, O., MüllerTrutwin, M., 2018. Interferon-associated therapies toward HIV control; The back and forth. Cytok. Growth Factor Rev., 40: 99-112. https://doi. org/10.1016/j.cytogfr.2018.03.004

Ortiz, A.R., Strauss, C.E. and Olmea, O., 2002. MAMMOTH (Matching molecular models obtained from theory): An automated method for model comparison. Protein Sci., 11: 2606-2621. https://doi.org/10.1110/ps.0215902

Peng, F.W., Duan, Z.J., Zheng, L.S., Xie, Z.P., Gao, H.C., Zhang, H., Li, W.P. and Hou, Y.D., 2007. Purification of recombinant human interferonepsilon and oligonucleotide microarray analysis of interferon-epsilon-regulated genes. Protein Expr. Purif., 53: 356-362. https://doi.org/10.1016/j. pep.2006.12.013
Robertsen, B., Bergan, V., Rokenes, T., Larsen R. and Albuquerque, A., 2003. Atlantic Salmon interferon genes: cloning, sequence analysis, expression and biological activity. J. Interferon Cytokine Res., 23: 601-612. https://doi. org/10.1089/107999003322485107

Roy, A., Kucukural, A. and Zhang, Y., 2010. I-TASSER: A unified platform for automated protein structure and function prediction. Nat. Protoc., 5: 725-738. https://doi.org/10.1038/nprot.2010.5

Sambrook, J., Frisch, E. and Maniatis, T., 1989. Molecular cloning: A laboratory manual, second ed., Cold Spring Harbor Laboratory Press, New York.

Samudzi, C.T., Burton, L.E. and Rubin, J.R., 1991. Crystal structure of recombinant rabbit interferongamma at $21 \pm 7 \mathrm{AI}$ resolution. J. biol. Chem., 266: 21791-21797. https://doi.org/10.2210/pdb1rig/pdb

Sanger, F., Nicklen, S. and Coulson, A.R., 1977. DNA sequencing with chain-terminating inhibitors. Proc. natl. Acad. Sci. U. S. A., 74: 5463-5467. https://doi. org/10.1073/pnas.74.12.5463

Shepherd, J., Waugh, N. and Hewitson, P., 2000. Combination therapy (interferon alfa and ribavirin) in the treatment of chronic hepatitis $\mathrm{C}$ : A rapid and systematic review. Hlth. Technol. Assess., 4: 1-67. https://doi.org/10.3310/hta4330

Srikanth, K., Yoganand, K.N.R., Smita, H., Ranjith Kumar, C.T., Anand, B. and Sivaprakasam, S., 2019. Novel glycosylated human interferon alpha $2 \mathrm{~b}$ expressed in glycoengineered Pichia pastoris and its biological activity: N-linked glycoengineering. Enzy. Mic. Technol., 128: 49-58. https://doi.org/10.1016/j.enzmictec.2019.05.007

Steinbach, F., Mauel, S. and Beier, I., 2002. Recombinant equine interferons: Expression cloning and biological activity. Vet. Immunol. Immunopathol., 84: 83-95. https://doi.org/10.1016/ S0165-2427(01)00396-8

Suresh, M., Karaca, K., Foster, D. and Sharma, J.M., 1995. Molecular and functional characterization of Turkey interferon. J. Virol., 69: 8159-8163. https:// doi.org/10.1128/JVI.69.12.8159-8163.1995

Tayal, V. and Kalra, B.S., 2008. Cytokines and anticytokines as therapeutics an update. Eur. J. Pharmacol., 579: 1-12.

Tian, L., Zhao, P., Ma, B., Guo, G., Sun, Y. and Xing, M., 2014. Cloning, expression and antiviral bioactivity of Red-crowned crane interferon- $\alpha$. Gene, 544: 49-55. https://doi.org/10.1016/j.gene.2014.04.036

Towbin, H., Staehelin, T. and Gordon, J., 1979. Electrophoretic transfer of proteins from 
polyacrylamide gels to nitrocellulose sheets: Procedure and some applications. Proc. natl. Acad. Sci. USA, 76: 4350-4354. https://doi.org/10.1073/ pnas.76.9.4350

Vacchelli, E., Galluzzi, L., Eggermont, A., Galon, J., Tartour, E., Zitvogel, L. and Kroemer, G., 2012. Trial Watch: Immunostimulatory cytokines. Oncoimmunology, 1: 493-506. https://doi. org/10.4161/onci.20459

Vacchelli, E., Eggermont, A., Fridman, W.H., Galon, J., Zitvogel, L., Kroemer, G., Galluzzi, L., 2013. Trial watch: Immunostimulatory cytokines. Oncoimmunology, 2: E24850. https://doi. org/10.4161/onci.24850

van de Loosdrech, A.A., Nennie, E., Ossenkoppele, G.P., Beelen, R.H.J. and Langenhuijsen, M.A.C., 1991. Cell mediated cytotoxicity against U937 cells by human monocytes and macrophages in a modified colorimetric MTT assay: A methodological study. J. Immunol. Met., 141: 15-22. https://doi. org/10.1016/0022-1759(91)90205-T

Wang, X., Li F., Han, M., Jia, S., Wang, L., Qiao, X., Jiang, Y., Cui, W., Tang, L., Li, Y. and Xu, Y.G., 2020. Cloning, prokaryotic soluble expression, and analysis of antiviral activity of two novel feline IFN- $\omega$ proteins. Viruses, 12: pii: E335. https://doi. org/10.3390/v12030335

Yang, W., Jiang, C., Xia, W., Ju, H., Jin, S., Liu, S., Zhang, L., Ren, G., Ma, H., Ruan, M. and Hu, J., 2019. Blocking autophagy flux promotes interferonalpha-mediated apoptosis in head and neck squamous cell carcinoma. Cancer Lett., 451: 3447. https://doi.org/10.1016/j.canlet.2019.02.052

Zhang, Y., Li, X., Zhang, Y., Wang, L., Xu, J., Du, J. and Guan, Y., 2019. Pegylated interferon $\alpha$ inhibits the proliferation of hepatocellular carcinoma cells by down regulating miR-155. Annls Hepatol., 18: 494500. https://doi.org/10.1016/j.aohep.2018.11.007 